\title{
С.М. Мальований
}

\section{КАТОДНІ МАТЕРІАЛИ ДЛЯ НАТРІЙ-ЙОННИХ ВТОРИННИХ ДЖЕРЕЛ СТРУМУ ЗІ СТРУКТУРАМИ, ПОХІДНИМИ ВІД СТРУКТУРИ КАМ'ЯНОЇ СОЛІ}

\author{
${ }^{1}$ Інститут загальної та неорганічної хімії ім. В.І. Вернадського НАН України, \\ просп. Академіка Палладіна, 32/34, Київ, 03142, Украӥна \\ *e-mail: msergii@ukr.net
}

Розглянуто сучасний стан досліджень в області розробки та вдосконалення катодних матеріалів із шаруватими структурами, похідними від структури кам'яної солі, для натрієвих вторинних джерел струму. Сформульовано основні критерії актуальності та перспективності розробки та застосування натрій-йонних акумуляторів. Основну увагу сфокусовано на структурному аспекті стійкості матеріалів при циклюванні, застосуванні різних типів фаз шаруватих оксидів, фазовим переходам при деінтеркаляції та електрохімічним властивостям відомих катодів.

К л ю ч о в і с л о в а: натрій-йонні акумулятори, інтеркаляція натрію, шаруваті оксидні структури, катодні матеріали.

ВСТУП. На сьогодні найбільшим енергетичним ресурсом, що використовується у світі, є викопне паливо. Така ситуація викликає занепокоєння світової спільноти через негативний вплив на навколишнє середовище, глобальне потепління та нерівномірний доступ до таких ресурсів різних країн. У зв'язку з чим різноманітні джерела відновлюваної та чистої енергії набувають популярності в наші дні. Цьому, безумовно, сприяє i тарифна політика урядів багатьох країн, зокрема України. Для виробників чистої та відновлюваної енергії діють так звані "зелені тарифи", які сприяють інвестиціям в цей сегмент економіки. Проте слід зазначити, що основні джерела відновлюваної енергії, а для України це насамперед сонячна енергетика та значно меншою мірою вітрова, мають періодичний чи переривчастий характер виробництва та передачі електроенергії в мережу. Так, сонячні електростанції максимально продуктивні в середині світлового дня влітку, коли споживання електроенергії низьке - в години пік, увечері та ранком виробництво електроенергії мізерне, вночі його немає взагалі. Крім того, в наших широтах незначне виробництво електроенергії сонячними електростанціями в зимовий період, коли енергія користується більшим попитом - в Україні СЕС у січні виробляє близько 4 \% електроенергії від виробництва у липні. Тому введення в експлуатацію нових вітрових та, особливо, сонячних електростанцій приводить до дестабілізації роботи електромереж. У південних регіонах України, де СЕС відносно багато, ситуація зі стійкістю електромереж набуває загрозливого характеру. Таким чином, надзвичайно важливо стабілізувати мережу шляхом перерозподілу енергії у часі енерго-резервуючі пристрої та системи мають стати ключовими елементами для згладжування пікових навантажень та пікового виробництва. Серед усіх видів накопичення електроенергії використання великих ста- 
ціонарних вторинних батарей є дуже перспективним [1].

Найбільш успішним видом акумуляторів є літій-йонні джерела струму. Проте постійно зростаючий попит на літій, через його широке застосування в мобільних електронних пристроях та електромобілях, привів до того, що його ціна росте з року в рік [2]. Згідно 3 даними Dalhman Rose, запаси літію в земній корі на чотири порядки менші запасів натрію. При поточному рівні використання літію його запасів вистачить менш ніж на 150 років. А світові ціни на карбонат літію вже сьогодні майже у 30 разів перевищують ціни на карбонат натрію [3].

Натрій-йонні акумулятори є одними 3 найбільш перспективних кандидатів на заміну літій-йонних акумуляторів, особливо у великих батареях. Принцип їх роботи аналогічний: при заряді такої батареї йони натрію деінтеркалюють 3 матеріалу катода та впроваджуються в матеріал анода. Однак натріййонна система має ряд недоліків у порівнянні 3 літієвою: радіус катіона $\mathrm{Na}^{+}$складає 1.02 $\AA$, що значно більше ніж радіус катіона $\mathrm{Li}^{+}$ $(0.76 \AA ̊)$, крім того, окисно-відновний потенціал натрію (-2.71 В відносно стандартно-го водневого електрода) вищий за потенціал літію (-3.02 В). Ці параметри позначаються на величині щільності закумульованої енер-гії та швидкості процесів заряду-розряду у натрій-йонних акумуляторах. Тобто, з теоретичної точки зору, натрій-йонні акумулятори напевно не досягнуть таких щільностей енергії та такої швидкості заряд-розряду, яких досягли літієві батареї, і не зможуть зайняти нішу портативних електронних пристроїв. Однак натрієві батареї незамінні для великих акумуляторів, які обслуговують електричні мережі, оскільки кінетика електрохімічних процесів менш важлива, а критичним параметром є ціна акумулятора — чинником $\epsilon$ не тільки вартість катодного чи анодного матеріалу, при синтезі якого використовують дешевший натрій, але і вартість струмовідводів, адже для натрієвих анодів є можливість замінити цінну мідь на значно дешевшу алюмінієву фольгу [4].

Катодні матеріали з шаруватою структурою. Для забезпечення високої щільності енергії вторинної батареї та кінетики процесів заряду і розряду важливу роль відіграє матеріал катода. Серед багатьох кандидатів на роль основного катодного матеріалу для натрієвих вторинних джерел струму особливу увагу привертають шаруваті оксиди $\mathrm{Na}_{x} \mathrm{MO}_{2}$ ( $\mathrm{M}=\mathrm{Ti}, \mathrm{V}, \mathrm{Cr}, \mathrm{Mn}, \mathrm{Fe}, \mathrm{Co}, \mathrm{Ni}$ чи суміш кількох елементів), через високу ємність і щільність енергії, стабільність при циклюванні, простоту структури та способів приготування. Натрійвмісні шаруваті оксиди мають вищу стійкість структури, ніж літієві аналоги [5], тому демонструють високу ємність, що в свою чергу обумовлює для таких катодних матеріалів еквівалентну чи навіть вищу щільність енергії у порівнянні з літієвими шаруватими оксидами [6].

Шаруваті оксиди загальною формулою $\mathrm{Na}_{x} \mathrm{MO}_{2}$ складені 3 шарів $\mathrm{MO}_{6}$, де атом $3 d$ елемента знаходиться в октаедричному оточенні, та шарів катіонів натрію, що розміщуються між шарами $\mathrm{MO}_{6}$. Натрієві шаруваті оксиди можуть бути синтезовані у вигляді фаз О3, Р2 чи Р3 в залежності від того, яке оточення у катіона натрію та скільки оксидних шарів входять до елементарної комірки [7]. Буква вказує на просторову будову пустоти, утвореної атомами кисню, яку займає $\mathrm{Na}: \mathrm{O}$ - октаедр, Р - тригональна призма, а цифра - на кількість неповторних за будовою шарів, розміщених між оксидними шарами $\mathrm{MO}_{6}$. Для шаруватих натрісвих складних оксидів $\mathrm{Na}_{x} \mathrm{MO}_{2}$ фаза О3, як правило, спостерігається для складів, де $x$ знаходиться в межах $0.7 \leq x \leq 1.0$, оксидні шари $\mathrm{MO}_{6}$ вкладаються згідно з моделлю АВСАВС, а 
катіон натрію орієнтований до однієї грані та одного ребра (рис. 1). Фаза Р2 в основному характерна для $x \approx 0.67$, оксидні шари складені відповідно до конфігурації АВАВ, а катіон натрію орієнтований виключно на грані чи тільки на ребра. Що стосується фази Р3, характерної для складів, де $x \approx 0.5$, тут оксидні шари впорядковані згідно 3 моделлю ABBCCA, а катіон натрію орієнтований на одну грань октаедра $\mathrm{MO}_{6}$ та на три грані трьох октаедрів 3 протилежного оксидного шару.

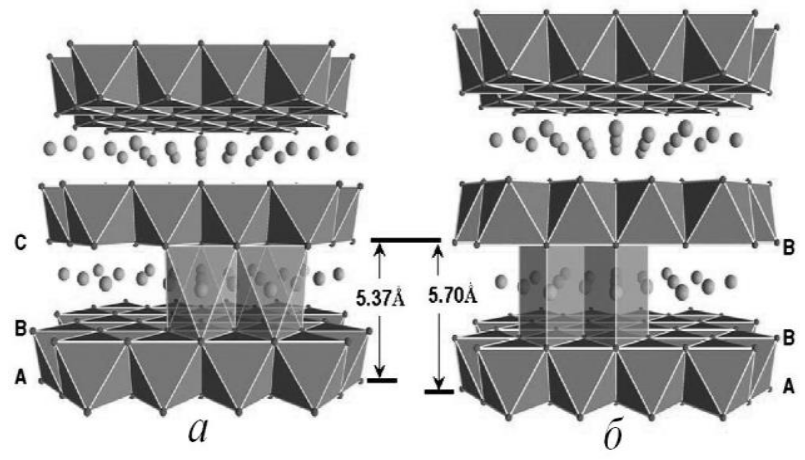

Рис. 1. Структура шаруватих оксидів: $a$ $\mathrm{NaVO}_{2}$ (О3-фаза); $\sigma-\mathrm{Na}_{0.7} \mathrm{VO}_{2}$ (Р2-фаза). Відмічено порядок розташування аніонних шарів (кулі) та міжшарова відстань [12].

Електрохімічна поведінка таких матеріалів сильно залежить від структури фази, не тільки через кількість натрію в вихідному матеріалі, але також визначається стабільністю кожного шару структури та кінетикою, обумовленою оточенням катіону натрію. Наприклад, фаза О3 зазвичай зазнає серії фазових перетворень через ковзання шарів під час електрохімічного циклювання [31]. Не дивлячись на те, що О3-фаза демонструє значно вищу ємність першого заряду через суттєво вищий вміст катіонів натрію у вихідному матеріалі, в цілому, кращі загальні електрохімічні характеристики при тривалому циклюванні отримані саме для матеріалів зі структурою фази Р2 у зв'язку з меншим бар'єром дифузії катіонів натрію та вищою йонною провідністю [8-10]. Транспортні властивості сильно залежать від природи $3 d$-елемента М для $\mathrm{Na}_{x} \mathrm{MO}_{2}$. Так, сполуки марганцю та хрому проявляють властивості напівпровідника, а кобальту - металічні властивості [11]. Крім того, фаза Р2 вважається структурно більш стабільною, ніж фаза О3, яка зазнає серію фазових перетворень при деінтеркаляції/інтеркаляції катіонів натрію при кімнатній температурі.

Електродні матеріали на основі $\mathrm{Na}_{x} \mathrm{VO}_{2}$. Катодні матеріали для натрієвих джерел струму на основі оксидів ванадію, безумовно, можуть мати лише науковий інтерес, оскільки жодного практичного економічно обгрунтованого застосування у великих акумуляторах бути не може через високу ціну на ванадій, яка у багато разів вища ціни на літій, і цей факт підриває саму економічну концепцію створення дешевих натрієвих батарей.

Твердофазною взаємодією вдалося отримати дві фази натрій ванадієвих оксидів $\mathrm{NaVO}_{2}$ та $\mathrm{Na}_{0.7} \mathrm{VO}_{2}$ і вивчено їх електрохімічні властивості та структуру [12]. Встановлено, що O3-фаза $\mathrm{NaVO}_{2}$ демонструє моноклінне викривлення, а P2-фаза $\mathrm{Na}_{0.7} \mathrm{VO}_{2}$ кристалізується у гексагональній симетрії. При електрохімічному тестуванні при потенціалах 1.2-2.5 В відносно $\mathrm{Na}^{+} / \mathrm{Na}$ струмами $\mathrm{C} / 20$, незважаючи на множинні фазові переходи, яким відповідають численні плато на заряд/розрядних кривих (рис. 2), обидві фази показують високооборотні електрохімічні процеси при глибині деінтеркаляції/інтеркаляції $0.5 \mathrm{Na} 3$ тією різницею, що Р2-фаза має меншу поляризацію у порівнянні 3 фазою О3. Циклічна вольтамперометрія для обох фаз показує суттєву відмінність у вигляді кривих, що означає різні механізми деінтеркаляції/інтеркаляції катіонів натрію. Крім того, проведення in situ РФА-досліджень показало, що P2-фаза $\mathrm{Na}_{0.7} \mathrm{VO}_{2}$ залишається стабільною у всьому інтервалі електрохімічного циклю- 
вання, зазнаючи лише комплексних змін параметрів елементарної комірки [12].
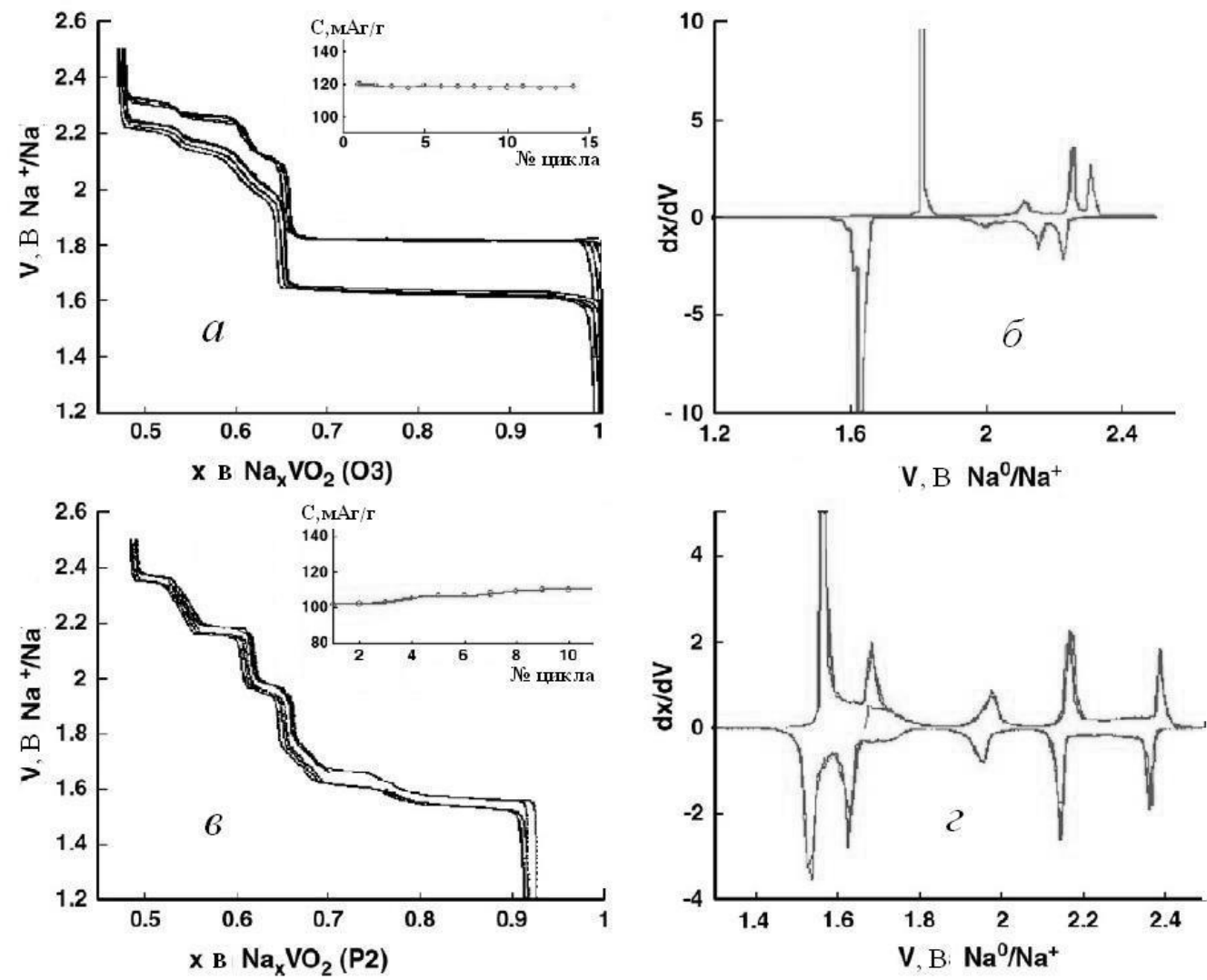

Рис. 2. Заряд-розрядні криві для $\mathrm{NaVO}_{2}\left(\mathrm{O} 3\right.$-фаза) (a), $\mathrm{Na}_{0.7} \mathrm{VO}_{2}(\mathrm{P} 2$-фаза) (в) та пов'язані з ними відповідно (б) і (2), похідні цих кривих [12].

Також фаза $\mathrm{O} 3 \mathrm{NaVO}_{2}$ була отримана шляхом відновлення $\mathrm{NaVO}_{3}$ в атмосфері водню [14]. Показано схожу поведінку матеріалу при фазових переходах, як і для О3-фази, отриманого твердофазною взаємодією оксидів. При електрохімічному тестуванні фази O3 виявлено сильну поляризацію, що обумовлено низькою кінетикою процесів інтеркаляції/деінтеркаляції. Значна різниця в поляризації для фаз О3 та Р2 може бути пояснена різним механізмом дифузії катіонів $\mathrm{Na}$ у структурах. Так, у структурі типу О3 катіони натрію рухаються крізь проміжну тетраедричну пустоту, що є складним для великого катіона Na. Тоді як для випадку фази Р2 катіони натрію проходять через нижчий бар'єр дифузії. Крім того, слід враховувати, що відстань між шарами $\mathrm{MO}_{6}$ для Р2-фази значно більша, ніж у О3, що також впливає на швидкість дифузії $\mathrm{Na}^{+}$.

Незважаючи на те, що матеріали на основі оксидів ванадію 3 шаруватою структурою показують високу стабільність при електрохімічному циклюванні та мають значну оборотну ємність ( 125 мАг/г), враховуючи, що більша частина цієї ємності знаходиться в області потенціалів 1.6-1.8 В, такий матеріал не можна ефективно використати ні як катод, ні як анод.

Електродні матеріали на основі $\mathrm{Na}_{x} \mathrm{CrO}_{2}$. 
Ранні дослідження електрохімічної активності $\mathrm{NaCrO}_{2}$ виявили, що ємність близько 120 мАг/г може бути досягнута, що відповідає інтеркаляції/деінтеркаляції $0.48 \mathrm{Na}$, і цей процес відбувається у вузькому інтервалі потенціалів близько 3 В, а заряд/розрядні криві за формою близькі до плато [15]. Матеріал демонструє також і хорошу кінетику електрохімічних процесів. Для порівняння, літієвий аналог такого матеріалу не має суттєвої оборотної ємності (менше $10 \mathrm{мАг/г),} \mathrm{хіба} \mathrm{що}$ крім першого заряду - 55 мАг/Г (рис. 3,4).

Фазові перетворення матеріалу при глибокій деінтеркаляції катіонів натрію, що призводить до повного руйнування шаруватої структури, вивчено з метою стабілізації цього процеса матеріалу при електрохімічному циклюванні [16]. За допомогою методів рентгенофазового аналізу та дифракції електронів продемонстровано, що $\mathrm{Na}_{x} \mathrm{CrO}_{2}(0 \leq x \leq 1)$ залишається у шаруватій структурі при деінтеркаляції катіонів натрію без міграції катіонів хрому аж до досягнення складу $\mathrm{Na}_{0.4} \mathrm{CrO}_{2}$. Подальше вилучення катіонів $\mathrm{Na} 3$ матеріалу спричиняє перетворення Р'3-фази шаруватого $\mathrm{Na}_{0.4} \mathrm{CrO}_{2}$ у кубічну структуру $\mathrm{CrO}_{2}$, що $\epsilon$ електрохімічно малоактивною. В іншій подібній роботі показано, що при досягненні зарядного потенціалу у $3.8 \mathrm{~B} \mathrm{у} \mathrm{Na} / \mathrm{Na}$ відбувається різке скорочення відстані між шарами $\mathrm{MO}_{6}$, яке супроводжується міграцією катіонів хрому 3 шарів до міжшарового просто-ру, що приводить до необоротних змін структури [17].

Для того, щоб продемонструвати можливість до застосування такого катодного матеріалу у практичних натрій-йонних акумуляторах, було досліджено реакційну стійкість $\mathrm{Na}_{x} \mathrm{CrO}_{2}$ в електролітах на органічній основі при різних температурах [18]. Встановлено відсутність екзотермічного ефекту при нагріванні системи 3 деінтеркальованого хроміту натрію $\mathrm{Na}_{0,5} \mathrm{CrO}_{2}$ i суміші розчинни- ків етиленкарбонат-диетилкарбонат в інтервалі температур 50-350 ${ }^{\circ} \mathrm{C}$, тоді як, наприклад, $\mathrm{Li}_{0 .,}, \mathrm{FePO}_{4}$ проявляє хімічну активність у розчинниках при $300{ }^{\circ} \mathrm{C}$. Автори прийш-

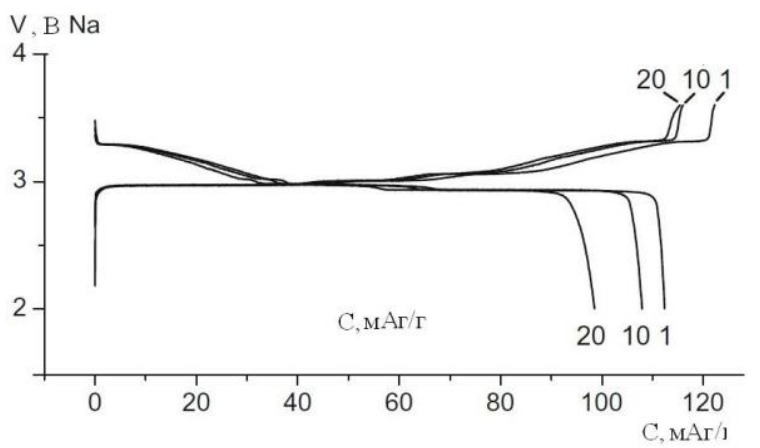

Рис. 3. Гальваностатичний заряд-розряд для комірки $\mathrm{Na} \| \mathrm{NaCrO}_{2}$ між 2.0 та $3.6 \mathrm{~B}$ в $1 \mathrm{M} \mathrm{NaClO}_{4}$ у пропіленкарбонаті [15].

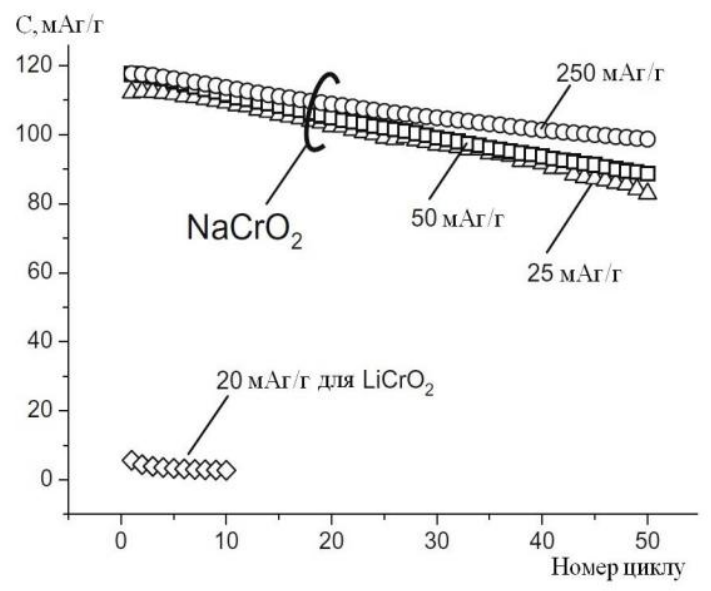

Рис. 4. Залежність ємності від номера циклу при різних зарядних струмах для комірки $\mathrm{Na} \| \mathrm{NaCrO}_{2}$ між 2.0 та $3.6 \mathrm{~B}$ в $1 \mathrm{M} \mathrm{NaClO}_{4}$ у пропіленкарбонаті.

ли до висновку, що хроміт натрію $є$ найкращим катодним матеріалом для застосування натрій-йонного акумулятора в широкому інтервалі температур.

Показано ефективне застосування катодного матеріалу $\mathrm{Na}_{x} \mathrm{CrO}_{2}$ у вторинних батареях 3 електролітом на основі йонної рідини при температурах до $90{ }^{\circ} \mathrm{C}$ [19], де більшість інших матеріалів $є$ нестабільними. У цій роботі продемонстровано відмінну стабільність 
матеріалу при циклюванні, коли він зберігає понад 90 \% від вихідної ємності після 1000 циклів глибокого заряд/розряду та має високу ефективність відтворення енергії при заряді/ розряді у $97.5 \%$ при силі струму у $\mathrm{C} / 5$.

Для покращення електрохімічних властивостей $\mathrm{NaCrO}_{2}$ як катодного матеріалу було успішно реалізовано стратегію нанесення вуглецевого покриття на зерно складного оксиду [20]. Матеріал $\mathrm{C}-\mathrm{NaCrO}_{2}$ показав високу ємність у 125 мАг/г, стабільність при циклюванні та неочікувано високу ємність у 99 мАг/г при надзвичайно високих струмах заряд/розряду у 150 А, що відповідає 27 секундам повного розряду.

При дослідженні четвертинної оксидної системи $\mathrm{Na}-\mathrm{Cr}-\mathrm{Ti}-\mathrm{O}$ в області існування шаруватих структур, похідних від структури кам'яної солі $\mathrm{Na}_{x} \mathrm{Cr}_{x} \mathrm{Ti}_{1-x} \mathrm{O}_{2}$, було виявлено існування трьох фаз: О3-фази, стійкої в інтервалі $0.8 \leq x \leq 1$ до граничного складу $\mathrm{Na}_{0.8} \mathrm{Cr}_{0.8}$ $\mathrm{Ti}_{0.2} \mathrm{O}_{2}$; P2-фазу складу $\mathrm{Na}_{2 / 3} \mathrm{Cr}_{2 / 3} \mathrm{Ti}_{1 / 3} \mathrm{O}_{2}$ та P3фазу складу $\mathrm{Na}_{0.58} \mathrm{Cr}_{0.58} \mathrm{Ti}_{0.42} \mathrm{O}_{2}$. Обидві, $\mathrm{P} 2$ та P3 фази, демонструють високу стабільність при циклюванні: Р2-фаза як катодний матеріал, а Р3-фаза як анодний, причому потенціал розрядної кривої Р2-фази значно вищий (на 0.5-0.7 В), ніж у О3-фази $\mathrm{NaCrO}_{2}$ [21].

Електродні матеріали на основі $\mathrm{Na}_{x} \mathrm{MnO}_{2}$. $\mathrm{Na}_{x} \mathrm{MnO}_{2}$ - це один 3 перших і найбільш охарактеризованих оксидів 3 шаруватою структурою. В даному огляді розглядаються матеріали лише з $2 D$-структурою, незважаючи на те, що для цієї системи характерно і утворення значної кількості канальних $3 D$-структур, які теж широко досліджуються. Серед $2 D$ фаз виділяють три різні структури в залежності від стехіометрії та способу синтезу: Р2фаза $\mathrm{Na}_{0.7} \mathrm{MnO}_{2+y}, \alpha-\mathrm{NaMnO}_{2}$ та $\beta-\mathrm{NaMnO}_{2}$. Фаза $\alpha-\mathrm{NaMnO}_{2}$ має моноклінну симетрію, тоді як $\beta-\mathrm{NaMnO}_{2} \in$ орторомбічною фазою [22]. При електрохімічному тестуванні $\alpha-\mathrm{NaMnO}_{2}$ лише $0.22 \mathrm{Na}$ може бути деінтеркальовано оборотно, а для фази $\beta-\mathrm{NaMnO}_{2}$ циклюється лише $0.15 \mathrm{Na}$. Низька мобільність катіонів натрію обумовлена високою поляризацією в $\alpha-\mathrm{NaMnO}_{2}$, ефект Яна-Теллера, що спостерігається при глибшій деінтеркаляції, понижує коефіцієнт дифузії $\mathrm{Na}^{+}$ще більше. Для Рфази $\mathrm{Na}_{0.7} \mathrm{MnO}_{2}$ усі електрохімічні дослідження були проведені для збагачених гексагональних фаз. Утворення твердих розчинів виявлено в інтервалі $0.45 \leq x \leq 0.85$ і Р2-фаза стійка в усьому інтервалі електрохімічної деінтеркаляції/інтеркаляції при потенціалі вище 2.0 В. Естафетний механізм $\left(\mathrm{Mn}^{3+} \leftrightarrow \mathrm{Mn}^{4+}\right)$ $\epsilon$ відповідальним за високу електронну провідність у $\mathrm{Na}_{x} \mathrm{MnO}_{2}$. Далі, ефект Яна-Теллера для $\mathrm{Mn}^{3+}$ підвищує локалізацію електронів і зниження коефіцієнту дифузії відбувається через $\mathrm{Na}^{+} / e^{-}$зв'язування [23].

Існує чіткий зв'язок між дефектною структурою $\mathrm{Na}_{0.7} \mathrm{MnO}_{2}$, електронними властивостями та електрохімічною поведінкою, що свідчить про відхилення від ідеальної стехіометрії при різних умовах синтезу, особливо, при різному парціальному тиску кисню. Навіть швидкість охолодження зразку після синтезу може мати великий ефект (рис. 5). У дослідженні [24] матеріали складу $\mathrm{Na}_{0.7} \mathrm{MnO}_{2+y}$ демонструють ємності, що відрізняються майже у два рази в залежності від того, був зразок охолоджений повільно чи загартований.

Через присутність у структурі $\mathrm{Na}_{0.7} \mathrm{MnO}_{2}$ високоспінових ян-теллерівських йонів $\mathrm{Mn}^{3+}$ спостерігається орторомбічне викривлення гратки. Такі допанти як катіони літію, магнію, нікелю та кобальту, які заміщують частину катіонів мангану ефективно пригнічують ян-теллерівське викривлення структури $\mathrm{i}$ тому приводять до ідеальної не викривленої Р2-фази навіть при невисоких температурах синтезу. Так, при частковому заміщенні катіонів мангану на електрохімічно неактивний магній фази $\mathrm{P} 2 \mathrm{Na}_{0.67} \mathrm{Mn}_{1-x} \mathrm{Mg}_{x} \mathrm{O}_{2}(0 \leq \mathrm{x} \leq 0.2)$, навіть на рівні $5 \%$ спостерігали значне по- 
кращення електрохімічних властивостей i стабільності при циклюванні без суттєвої зміни ємності [25]. При збільшенні ступеня заміщення мангану на катіони $\mathrm{Mg}^{2+}$ заряд/розрядні профілі стають плавними без помітних стадій, оскільки магній ефективно послаб-
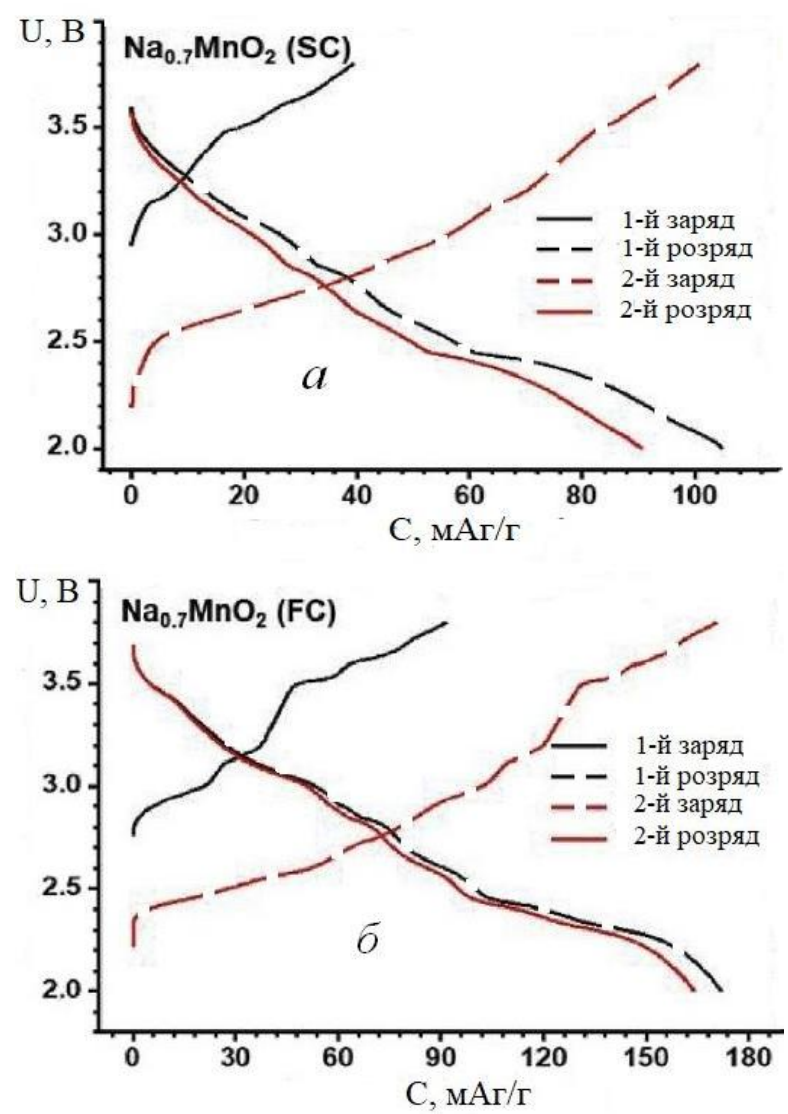

Рис. 5. Профілі гальваностатичних кривих для повільно охолодженого (SC) $(a)$ та загартованого (FC) (б) $\mathrm{Na}_{0.7} \mathrm{MnO}_{2}$ при струмах $\mathrm{C} / 10$ [21].

лює ефект Яна-Теллера, підвищуючи концентрацію йонів $\mathrm{Mn}^{4+}$. При досягненні стехіометрії $\mathrm{Na}_{0.67} \mathrm{Mn}_{0.72} \mathrm{Mg}_{0.28} \mathrm{O}_{2}$ ємність матеріалу може сягнути величини у 200 мАг/г. Така висока ємність, що виходить за межі теоретичної, яка базується на роботі $\mathrm{Mn}^{3+} / \mathrm{Mn}^{4+}$ окисно-відновної пари, вірогідно, частково забезпечується електрохімічною участю оксидних йонів аналогічно до процесів у твердих розчинах на основі $\mathrm{Li}_{2} \mathrm{MnO}_{3}$ для літій- йонних джерел струму [26].

Катодні матеріали на основі $\mathrm{Na}_{x} \mathrm{FeO}_{2}$. У залежності від умов синтезу вдається отримати $\alpha$ - чи $\beta-\mathrm{NaFeO}_{2}$, вже добре вивчені та охарактеризовані, проте лише низькотемпературна $\alpha-\mathrm{NaFeO}_{2}$-фаза проявляє електрохімічну активність. O3-фаза $\alpha-\mathrm{NaFeO}_{2}$ була охарактеризована структурно та електрохімічно відносно недавно [27]. Вихідний матеріал при гальваностатичному заряд/розряді демонструє плоский профіль кривої, близький до плато, якщо циклюється в межах не вище 33 В відносно металевого натрію. Систематична зміна верхньої межі зарядного потенціалу показує різку залежність необоротних структурних змін матеріалу від граничної напруги заряду, коли ця межа починає перевищувати 3.5 В (рис. 6).

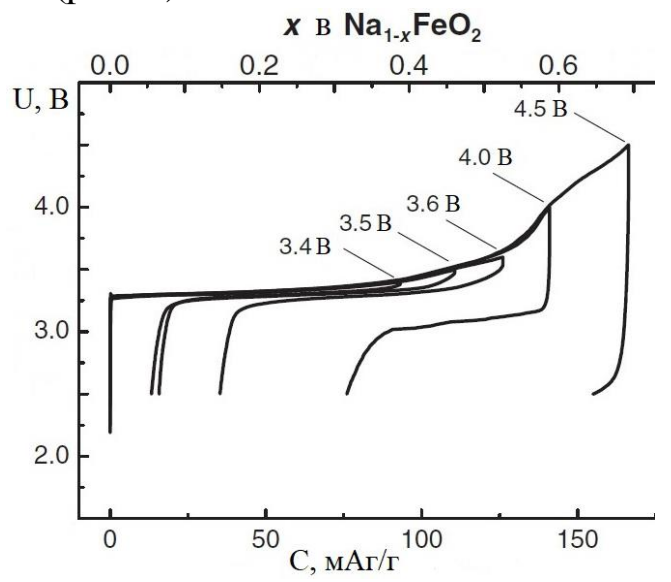

Рис. 6. Перші заряд-розрядні криві для комірки $\mathrm{Na} / \mathrm{NaFeO}_{2}$ з різним граничним потенціалом заряду [27].

Хоча ємність першого заряду постійно зростає по мірі підвищення напруги, так само швидко зменшується оборотність і ємність при розряді. Відмінна оборотність і незначна поляризація спостерігаються, якщо катод циклюють у межах 2.5-3.4 В, тоді оборотна ємність складає близько 100 мАг/г, що приблизно відповідає інтеркаляції/деінтеркаляції 0.3 $\mathrm{Na}$. За таких умов тестування ефективність процесу заряду/розряду першого циклу становить 
83 \% і далі стрімко зростає до 97 \% для другого та наступних циклів.

Оскільки катодні матеріали на основі оксиду заліза викликають величезний інтерес у першу чергу в зв'язку з доступністю і низькою ціною сировини, значні зусилля дослідників спрямовані на стабілізацію складних оксидів 3 шаруватою структурою на основі заліза шляхом отримання фаз, що містять інші $3 d$-елементи ( $\mathrm{Mn}, \mathrm{Ni}, \mathrm{Co}$ чи інші), для того щоб суттєво збільшити ємність, стабільність при циклюванні, підвищити потенціал розряду та відповідно підвищити щільність акумульованої енергії такою коміркою. Одним із найбільш вдалих поєднань є вивчення систем на основі $\mathrm{Na}_{x} \mathrm{FeO}_{2} 3$ додаванням мангану. Це має драматичний вплив на покращення характеристик катодного матеріалу, а також мало підвищує ціну, зважаючи на доступність мангану. Так, Р2-фаза складу $\mathrm{Na}_{2 / 3} \mathrm{Fe}_{2 / 3} \mathrm{Mn}_{1 / 3} \mathrm{O}_{2}$ показує високу оборотну ємність, майже удвічі вищу за таку ж для $\alpha$ $\mathrm{NaFeO}_{2}$ і сягає понад 180 мАг/Г при середньому потенціалі розряду $3 \mathrm{~B}$, демонструючи при цьому стабільність циклювання в інтервалі потенціалів 1.5-4.2 В [28]. Інші досліджувані фази, такі як $\mathrm{P} 2 \mathrm{Na}_{2 / 3} \mathrm{Fe}_{1 / 2} \mathrm{Mn}_{1 / 2} \mathrm{O}_{2}$ та $\mathrm{P} 2 \mathrm{Na}_{2 / 3} \mathrm{Fe}_{1 / 3} \mathrm{Mn}_{2 / 3} \mathrm{O}_{2}$ також мають високі $\mathrm{\epsilon M-}$ ності та стабільність при циклюванні. Порівняння електрохімічних характеристик фаз Р2 $\mathrm{Na}_{2 / 3} \mathrm{Fe}_{1 / 2} \mathrm{Mn}_{1 / 2} \mathrm{O}_{2}$ та $\mathrm{O} 3 \mathrm{NaFe}_{1 / 2} \mathrm{Mn}_{1 / 2} \mathrm{O}_{2}$ показує, що в цілому Р2-фаза має значно кращі електрохімічні характеристики і вищу ємність — до 190 мАг/г, тоді як О3-фаза досягає ємності у 110 мАг/Г і циклюється гірше [29-31]. Але слід зазначити, що, хоча Р2-фази $\mathrm{Na}_{2 / 3} \mathrm{Fe}_{1 / 2} \mathrm{Mn}_{1 / 2} \mathrm{O}_{2}$ та $\mathrm{Na}_{2 / 3} \mathrm{Fe}_{1 / 3} \mathrm{Mn}_{2 / 3} \mathrm{O}_{2}$ і показують дещо більшу ємність у порівнянні 3 Р2-фазою складу $\mathrm{Na}_{2 / 3} \mathrm{Fe}_{2 / 3} \mathrm{Mn}_{1 / 3} \mathrm{O}_{2}$, однак вони $є$ натрій-дефіцитними, тобто для отримання максимальної ємності їм потрібна додаткова кількість натрію з аноду, що досить незручно виконати на практичному вироб- ництві, а тому матеріали на основі фази $\mathrm{Na}_{2 / 3} \mathrm{Fe}_{2 / 3}-\mathrm{Mn}_{1 / 3} \mathrm{O}_{2}$ у даній системі поки поза конкуренцією.

Катодні матеріали на основі $\mathrm{Na}_{x} \mathrm{CoO}_{2}$. Враховуючи ціну на сполуки кобальту, яка перевищує ціну сполук літію, можна 3 впевненістю стверджувати, що ніякого практичного застосування катодних матеріалів на базі оксиду кобальту у великих натрій-йонних акумуляторах не буде. Можливе застосування кобальту лише у вигляді міноритарної добавки за умови різкого підвищення електрохімічних характеристик катодного матеріалу. 3 іншого боку, катодні матеріали на основі $\mathrm{Na}_{x} \mathrm{CoO}_{2}$, безумовно, викликають певний науковий інтерес.

O3-фаза $\mathrm{Na}_{x} \mathrm{CoO}_{2}$ може бути деінтеркальована електрохімічно до $\mathrm{Na}_{0,5} \mathrm{CoO}_{2}$, зазнаючи при цьому перетворення у фазу Р3, що відображається у вигляді множинних плато на гальваностатичних кривих в інтервалі 0.67 $\leq x \leq 0.8$. Фазові перетворення під час деінтеркаляції/інтеркаляції детально вивчалися в електроліті $1 \mathrm{M} \mathrm{NaClO}_{4}$ в пропіленкарбонаті [32]. У залежності від вмісту натрію можливе отримання кількох фаз $\mathrm{Na}_{x} \mathrm{CoO}_{2}: \mathrm{O} 3$ $(x=1), \mathrm{O}^{\prime} 3(x=0.77), \mathrm{P} 2(0.64 \leq x \leq 0.77)$ та P'3 $(0.55 \leq x \leq 0.60)$. При деінтеркаляції вихідного $\mathrm{NaCoO}_{2}$ матеріал проходить перетворення в перелічені фази і цим пояснюється складний вигляд кривих гальваностатичного заряду. Такі перетворення супроводжуються і значною поляризацією.

Втім, якщо вихідною взяти синтезовану Р2-фазу, стійку в інтервалі вмісту натрію $(0.46 \leq x \leq 0.83)$, складний вигляд зарядних кривих з багатьма плато теж присутній, що пояснюють процесами перерозподілу катіонів натрію в процесі деінтеркаляції. У цьому випадку низька поляризація та структурна стабільність обумовлюють високі характеристики при довготривалих випробуваннях. Ці перерозподілення катіонів $є$ наслідком електростатичного відштовхування катіонів на- 
трію, орієнтованого на грань октаедру $\mathrm{CoO}_{6}$ від катіону кобальту, а також електрон-електронної взаємодії в оксидному шарі. Інколи навіть незначної зміни концентрації катіонів натрію у 1-2 \% достатньо, щоб викликати таке перерозподілення [33, 34]. Звісно, наявність множинних фазових переходів, які розширюють інтервал потенціалів електрохімічних процесів до меж у 2-4 B, не покращує практичну можливість використання такого катодного матеріалу.

Електродні матеріали на основі $\mathrm{Na}_{x} \mathrm{NiO}_{2}$. Електрохімічні властивості $\mathrm{NaNiO}_{2}$ вивчалися багатьма дослідниками вже досить давно. О3-фаза $\mathrm{NaNiO}_{2}$ має ідеальну гексагональну симетрію при температурі вище $220{ }^{\circ} \mathrm{C}$, яка зазнає моноклінного викривлення при охолодженні, оскільки низькоспіновий катіон $\mathrm{Ni}^{3+}$ обумовлює сильний ефект Яна-Теллера, що супроводжується відхиленням співвідношення параметрів елементарної комірки $a / b$ від ідеального. За даними попередніх досліджень, лише $0.2 \mathrm{Na}$ на формульну одиницю можуть бути деінтеркальовані $3 \mathrm{O} 3 \mathrm{NaNiO}_{2}$, однак сучасніші дослідження [13] переглянули електрохімію цього матеріалу. При першому заряді ємність сягає 147 мАг/г, а наступний розряд показує $123 \mathrm{мАг/ \Gamma} \mathrm{у} \mathrm{діапа-}$ зоні потенціалів 3.75-1.25 В. Після 20 циклів заряд/розряду кулонівська ефективність процесу зростає до $99.2 \%$. При циклюванні в межах потенціалів 4.5-2.0 В ємність першого заряду зростає до 199 мАг/г, проте кулонівська ефективність нижча (86 \%), що супроводжується швидкою втратою ємності після 20 циклів. Зарядні криві мають складний характер 3 численними плато, що свідчить про серію фазових перетворень $\mathrm{NaNiO}_{2}$ під час електрохімічного процесу. Втрата ємності при глибокому розряді обумовлена неможливістю відновлення вихідної О’3-фази $\mathrm{NaNiO}_{2}$ при повному розряді [35].

Особливого значення набувають дослідження матеріалів на основі $\mathrm{NaNiO}_{2} 3$ добав- ками інших $3 d$-елементів, що дозволяє стабілізувати структуру, уникнути фазових переходів та покращити електрохімічні характеристики. Оскільки нікель цікавий тим, що має кілька ступенів окислення, що можуть бути використані в електрохімічних процесах та забезпечити високі потенціали, робіт то вивченню складних оксидів на основі оксиду нікелю в якості катодів з високою щільністю енергії є багато. Так, дослідження О3-фази складу $\mathrm{NaNi}_{0.5} \mathrm{Mn}_{0.5} \mathrm{O}_{2}$ методом гальваностатичного заряду-розряду показало стадійність електрохімічного процесу з наявністю 3 плато на кривих [36], в той же час Р2-фаза $\mathrm{Na}_{x} \mathrm{Ni}_{1 / 3} \mathrm{Mn}_{2 / 3} \mathrm{O}_{2}$ демонструє плавні зарядні криві без чітко вираженої стадійності [37] . Структурні дослідження методом рентгенофазового аналізу показали наявність чотирьох фазових переходів для вихідних О3-фаз до О'3 фази, далі до Р3, до Р'3 та Р'’3. При заряді вище 4.0 В відбувається фазовий перехід до О2-фази, який і обумовлює необоротність процесу та втрату ємності при розряді [38]. Початкова ємність О3-фази є вищою, через більший вміст натрію на формульну одиницю, але Р2-фаза має переважаючі характеристики при тривалому циклюванні, що обумовлено вищою структурною стабільністю.

Недавнє дослідження серії матеріалів загальною формулою $\mathrm{Na}_{a} \mathrm{Ni}_{(1-x-y-z)} \mathrm{Mn}_{x} \mathrm{Mg}_{y} \mathrm{Ti}_{z} \mathrm{O}_{2} /$ вуглець [39] показало можливість отримання матеріалу 3 характеристиками, близькими до характеристик катодних матеріалів літій-йонних акумуляторів, що виробляються промислово.

ВИСНОВКИ. Згідно $з$ концепцією натрієвої вторинної батареї як дешевої великої батареї, найбільш перспективними видаються катоди на основі оксидів хрому, мангану та заліза. Слід зазначити, що вже зараз створено та досліджено катодні матеріали для натрій-йонних акумуляторів, які мають ємності, порівняні з матеріалами комерціалізованих систем. Не зважаючи на помітні успіхи в 
розробці таких катодів, досі є ряд суттєвих викликів, це: низькі робочі потенціали; низький вміст натрію на формульну одиницю у P2-фазах, що зменшує теоретичну ємність матеріалів; стабільність структури катодів при тривалому циклюванні - більшість відомих катодних матеріалів зазнають фазових переходів при електрохімічному процесі, що негативно впливає на довготривалу роботу акумулятора; значна поляризація при електрохімічному процесі у натрієвих шаруватих оксидів. Ці виклики можуть бути вирішені шляхом зменшення розмірів часток матеріалу, модифікації поверхні часток провідними матеріалами, широким використанням стратегії ізовалентного та гетеровалентного заміщення у підгратці $3 d$-елемента.

КАТОДНЫЕ МАТЕРИАЛЫ ДЛЯ НАТРИЙ-ИОННЫХ ВТОРИЧНЫХ ИСТОЧНИКОВ ТОКА СО СТРУКТУРАМИ, ПРОИЗВОДНЫМИ ОТ СТРУКТУРЫ КАМЕННОЙ СОЛИ

\section{С.М. Малёваный *}

Институт общенй и неорганической химии им. В.И. Вернадского НАН Украины, просп. Академика Палладина, 32/34, Киев, 03142, Украина *e-mail: msergii@ukr.net

Рассмотрено современное состояние исследований в области разработки и усовершенствования катодных материалов со слоистыми структурами, производными от структуры каменной соли для натриевых вторичных истрчников тока. Сформулированы основные критерии актуальности и перспективности разработки и использования натрий-ионных акумуляторов. Основное внимание сфокусировано на структурном аспекте стойкости материалов при циклировании, применении различных типов фаз слоистых оксидов, фазовых переходах при деинтеркаляции и электрохимических свойствах известных катодов.

К л ю ч е в ы е с л о в а: натрий-ионные аккумуляторы, интеркаляция натрия, слоистые оксидные структуры, катодные материалы.
CATHODE MATERIALS OF ROCK SALT DERIVATIVE STRUCTURES FOR SODIUM-ION SECONDARY POWER SOURCES

S.M. Malovanyy*

\section{V.I.Vernadsky Istitute of General and Inorganic Chemistry of National Academy of Sciences of Ukraine, 32/34 Academic Palladin Avenue, Kyiv, 03142, Ukraine \\ *e-mail: msergii@ukr.net}

The rechargeable lithium-ion batteries have been dominating the portable electronic market for the past two decades with high energy density and long cycle-life. However, applications of lithium-ion batteries in large-scale stationary energy storage are likely to be limited by the high cost and availability of lithium resources. The room temperature Na-ion secondary battery have received extensive investigations for large-scale energy storage systems (EESs) and smart grids lately due to similar chemistry of "rocking-chair" sodium storage mechanism, lower price and huge abundance. They are considered as an alternative to lithium-ion batteries for large-scale applications, bringing an increasing research interests in materials for sodium-ion batteries. Although there are many obstacles to overcome before the Na-ion battery becomes commercially available, recent research discoveries corroborate that some of the cathode materials for the Na-ion battery have indeed advantages over its Li-ion competitors. Layered oxides are promising cathode materials for sodium ion batteries because of their high theoretical capacities. In this publication, a review of layered oxides $\left(\mathrm{Na}_{x} \mathrm{MO}^{2}, \mathrm{M}=\mathrm{V}, \mathrm{Cr}, \mathrm{Mn}, \mathrm{Fe}, \mathrm{Co}, \mathrm{Ni}\right.$, and a mixture of 2 or 3 elements) as a Na-ion battery cathode is presented. O3 and P2 layered sodium transition metal oxides $\mathrm{Na}_{x} \mathrm{MO}_{2}$ are a promising class of cathode materials for Na secondary battery applications. These materials, however, all suffer from capacity decline when the extraction of $\mathrm{Na}$ exceeds certain capacity limits. Understanding the causes of this capacity decay is critical to unlocking the potential of these materials for battery applications. Single layered oxide systems are well characterized not only for their electrochemical performance, but also for their structural transitions during the cycle. Binary oxides systems are investigated in order to address 
issues regarding low reversible capacity, capacity retention, operating voltage, and structural stability. Some materials already have reached high energy density, which is comparable to that of $\mathrm{LiFePO}_{4}$. On the other hand, the carefully chosen elements in the electrodes also largely determine the cost of SIBs. Therefore, earth abundant-based compounds are ideal candidates for reducing the cost of electrodes. Among all low-cost metal elements, cathodes containing iron, chromium and manganese are the most representative ones. The aim of the article is to present the development of $\mathrm{Na}$ layered oxide materials in the past as well as the state of the art today.

$\mathrm{K}$ e y w o r d s: sodium-ion batteries, sodium intercalation, layered oxide structures, cathode materials

\section{ЛІТЕРАТУРА}

1. Chou S., Yи Y. Next Generation Batteries: Aim for the Future // Adv. Energy Mater. -2017. -7. 1703223.

2. Pan H., Hu Y.-S., Chen L. Room-temperature stationary sodium-ion batteries for large-scale electric energy storage // Energy Environ. Sci. -2013. -6. -P. 2338-2360.

3. Slater M. D., Kim D., Lee E., Johnson Ch.S. Sodium-Ion Batteries // Adv. Funct. Mat. -2013. 23. -P. 947-958.

4. Bin D., Wang F., Tamirat A. G. et al. Progress in Aqueous Rechargeable Sodium-Ion Batteries // Adv. Energy Mater. -2018. -8. 1703008

5. Sangtae K., Ma X., Ong S., Ceder G. A. Comparison of destabilization mechanisms of the layered $\mathrm{Na}_{x} \mathrm{MO}_{2}$ and $\mathrm{Li}_{x} \mathrm{MO}_{2}$ compounds upon alkali deintercalation // Phys. Chem. Chem. Phys. -2012. -14. -P. 15571-15578.

6. Yabuuchi N., Kajiyama A., Iwatate J. et al. P2type $\mathrm{Na}(x)[\mathrm{Fe}(1 / 2) \mathrm{Mn}(1 / 2)] \mathrm{O}_{2}$ made from earthabundant elements for rechargeable $\mathrm{Na}$ batteries // Nat. Mater. -2012. -11. -P. 512-517.

7. Delmas C., Fouassier C., Hagenmuller P. Structural classification and properties of the layered oxides // Physica B+C. -1980. -99. -P. 81-85.

8. Kubota K., Yabuuchi N., Yoshida H. et al. Layered oxides as positive electrode for Na-ion bat- teries // MRS Bull. -2014. -39. -P. 416-422.

9. Mendiboure A., Delmas C., Hagenmuller P. Electrochemical intercalation and deinter-calation of $\mathrm{Na}_{x} \mathrm{MnO}_{2}$ bronzes // J. Solid State Chem. -1985. -57. -P. 323-331.

10. Saadoune I., Maazaz A., M'en'etrier M., Delmas $C$. On the $\mathrm{Na}_{x} \mathrm{Ni}_{0.6} \mathrm{Co}_{0.4} \mathrm{O}_{2}$ System: Physical and Electrochemical Studies // J. Solid State Chem. -1996. -122. -P. 111-117.

11. Ellis B.L., Nazar L.F. Sodium and sodiumion energy storage batteries // Curr. Opin. Solid State Mater. Sci. -2012. -16. -P. 168-177.

12. Hamani D., Ati M., Tarascon J.-M., Rozier P. $\mathrm{Na}_{x} \mathrm{VO}_{2}$ as possible electrode for Na-ion batteries // Electrochem. Commun. -2011. -13. -P. 938-941.

13. Bo S., Li X., Toumar A.J., Ceder G. Layered-toRock-Salt Transformation in Desodiated $\mathrm{Na}_{x} \mathrm{CrO}_{2}$ ( $x$ 0.4) // Chem. Mater. -2016. -28. -P. 1419-1429.

14. Kubota K., Ikeuchi I., Nakayama T. et al. New Insight into Structural Evolution in Layered $\mathrm{NaCrO}_{2}$ during Electrochemical So-dium Extraction // J. Phys. Chem C. -2015. -119, № 1. -P. 166-175.

15. Xia X., Dahn J. R. $\mathrm{NaCrO}_{2}$ is a Fundamentally Safe Positive Electrode Material for Sodium-Ion Batteries with Liquid Electrolytes // Electrochem. Solid-State Lett. -2011. -15. -P. A1-A4.

16. Fukunaga A., Nohira T., Hagiwara R. et al. Performance validation of sodium-ion bat-teries using an ionic liquid electrolyte // J. Appl. Electrochem. -2016. -46, № 4. -P. 487-496.

17. Yu Ch., Park J., Jung $H$.et al. $\mathrm{NaCrO}_{2}$ cathode for high-rate sodium-ion batteries // Energy Environ. Sci. -2015. -8. -P. 2019-2026.

18. Tsuchiya Y., Yabuuchi N. P2- and P3-Type $\mathrm{Na}_{x} \mathrm{Cr}_{x} \mathrm{Ti}_{1-x} \mathrm{O}_{2}$ Layered Oxides As Bi-Functional Electrode Materials for Rechargeable Sodium Batteries // ECS Meeting Abstracts -2016. MA 2016-02. -P. 768.

19. Parant J.-P., Olazcuaga R., Devalett M. et al. Sur quelques nouvelles phases de formule $\mathrm{Na}_{x}$. $\mathrm{MnO}_{2}(x \leqslant 1) / /$ J. Solid State Chem. -1971. -3. P. 1-11. 
20. Li X., Ma X., Su D. et al. Direct visualization of the Jahn-Teller effect coupled to Na ordering in $\mathrm{Na}_{5 / 8} \mathrm{MnO}_{2} / /$ Nat. Mater. -2014. -13. -P. 586-592.

21. Khan M.A., Han D., Lee G. et al. P2/O3 phaseintegrated $\mathrm{Na}_{0.7} \mathrm{MnO}_{2}$ cathode materials for sodiumion rechargeable batteries // J. Alloys and Compounds. -2019. -771. -P. 987-993.

22. Billaud J., Singh G., Armstrong A.R. et al. $\mathrm{Na}_{0.67} \mathrm{Mn}_{1-x} \mathrm{Mg}_{x} \mathrm{O}_{2}(0 \leq x \leq 0.2)$ : a high capacity cathode for sodium-ion batteries // Energy Environ. Sci. -2014. -7. -P. 1387-1391.

23. Yabuuchi N., Hara R., Kubota K. et al. A new electrode material for rechargeable sodium batteries: P2-type $\mathrm{Na}_{2 / 3}\left[\mathrm{Mg}_{0.28} \mathrm{Mn}_{0.72}\right] \mathrm{O}_{2}$ with anomalously high reversible capacity // J. Mater. Chem. A. -2014. -40. -P. 16851-16855.

24. Yabuuchi N., Yoshida H., Komaba S. Crystal Structures and Electrode Performance of Alpha$\mathrm{NaFeO}_{2}$ for Rechargeable Sodium Batteries // Electrochemistry. -2012. -80. -P. 716-719.

25. Zhao W., Tsuchiya Y., Yabuuchi N. Influence of Synthesis Conditions on Electrochemical Properties of P2-Type $\mathrm{Na}_{2 / 3} \mathrm{Fe}_{2 / 3} \mathrm{Mn}_{1 / 3} \mathrm{O}_{2}$ for Rechargeable Na Batteries // Small Methods. -2018. -1800032 .

26. Zhao J., Xu J., Lee D.H. et al. Electrochemical and thermal properties of P2-type $\mathrm{Na}_{2 / 3} \mathrm{Fe}_{1 / 3}$ $\mathrm{Mn}_{2 / 3} \mathrm{O}_{2}$ for Na-ion batteries // J. Power Sources. -2014. -264. -P. 235-239.

27. Dose W.M., Sharma N., Pramudita J.C. et al. Crystallographic Evolution of P2 $\mathrm{Na}_{2 / 3} \mathrm{Fe}_{0.4^{-}}$ $\mathrm{Mn}_{0.6} \mathrm{O}_{2}$ Electrodes during Elect-rochemical Cycling // Chem. Mater. -2016. -28. -P. 6342-6354.

28. Mortemard de Boisse B., Carlier D., Guignard M. et al. $\mathrm{P} 2-\mathrm{Na}_{x} \mathrm{Mn}_{1 / 2} \mathrm{Fe}_{1 / 2} \mathrm{O}_{2}$ Phase Used as Positive Electrode in Na Batteries: Structural Changes Induced by the Electrochemical (De)intercalation Process // Inorg. Chem. -2014. -53. -P. 11197-11205.

29. Shacklette L. W., Jow T. R., Townsend L. Rechargeable Electrodes from Sodium Cobalt Bronzes // J. Electrochem. Soc. -1988. -135. -P. 2669-2674.

30. Berthelot R., Carlier D., Delmas C. Electro- chemical investigation of the $\mathrm{P} 2 \mathrm{Na}_{x} \mathrm{CoO}_{2}$ phase diagram // Nat. Mater. -2011. -10. -P. 74-80.

31. Vassilaras P., Ma X., Li X., Ceder G. Electrochemical Properties of Monoclinic $\mathrm{NaNiO}_{2} / / \mathrm{J}$. Electrochem. Soc. -2013. -160. -P. A207-A211.

32. Ding J.J., Zhou Y. N., Sun Q. et al. Electrochemical properties of P2-phase $\mathrm{Na}_{0.74} \mathrm{CoO}_{2}$ compounds as cathode material for rechargeable sodium-ion batteries // Electrochim. Acta. -2013. -87. -P. 388-393.

33. Han M. H., Gonzalo E., Casas-Cabanas M., Rojo T. Structural evolution and electrochemistry of monoclinic $\mathrm{NaNiO}_{2}$ upon the first cycling process // J. Power Sources. -2014. -258. -P. 266-271.

34. Komaba S., Yabuuchi N., Nakayama T. et al. Study on the reversible electrode reaction of $\mathrm{Na}_{1-x} \mathrm{Ni}_{0.5} \mathrm{Mn}_{0.5} \mathrm{O}_{2}$ for a rechargeable sodium-ion battery // Inorg. Chem. -2012. -51. -P. 6211-6220.

35. Wang H., Yang B., Liao X.-Z et al. Electrochemical properties of $\mathrm{P} 2 \mathrm{Na}_{2 / 3}\left[\mathrm{Ni}_{1 / 3} \mathrm{Mn}_{2 / 3}\right] \mathrm{O}_{2}$ cathode material for sodium ion batteries when cycled in different voltage ranges // Electrochim. Acta. -2013. -113. -P. 200-204.

36. Lu Z., Dahn J. R. In Situ X-Ray Diffraction Study of P2 $\mathrm{Na}_{2 / 3}\left[\mathrm{Ni}_{1 / 3} \mathrm{Mn}_{2 / 3}\right] \mathrm{O}_{2} / / \mathrm{J}$. Electrochem. Soc. -2001. -148. -P. A1225-A1229.

37. Baker J., Heap R.J., Roche N. et al. High Performance Na-ion Batteries Based on Novel O3 Layered Oxide Cathode Materials // Int. Meeting on Lithium Batteries, Como. Italy, 2014.

38. Didier C., Guignard M., Denage C. et al. Electrochemical Na-deintercalation from $\mathrm{NaVO}_{2} / /$ Electrochem. Solid-State Lett. -2011. -14. -P. A75-A78.

39. Komaba S., Takei C., Nakayama T. et al. Electrochemical intercalation activity of layered $\mathrm{NaCrO}_{2}$ vs. $\mathrm{LiCoO}_{2} / /$ Electrochem. Commun. 2010. -12. -P. 355-358.

\section{REFERENCES}

1. Chou S., Yu Y. Next Generation Batteries: Aim for the Future. Adv. Energy Mater. 2017. 7: 1703223.

2. Pan H., Hu Y.-S., Chen L. Room-temperature stationary sodium-ion batteries for large-scale electric 
energy storage. Energy Environ. Sci. 2013. 6: 2338.

3. Slater M.D., Kim D., Lee E., Johnson Ch.S. Sodium-Ion Batteries. Adv. Funct. Mat. 2013. 23: 947.

4. Bin D., Wang F., Tamirat A. G., Suo L., Wang Y., Wang C., Xia Y. Progress in Aqueous Rechargeable Sodium-Ion Batteries. Adv. Energy Mater. 2018. 8: 1703008.

5. Sangtae K., Ma X., Ong S., Ceder G. A. Comparison of destabilization mechanisms of the layered $\mathrm{Na}_{x} \mathrm{MO}_{2}$ and $\mathrm{Li}_{x} \mathrm{MO}_{2}$ compounds upon alkali deintercalation. Physical Chemistry Chemical Physics. 2012. 14: 15571.

6. Yabuuchi N., Kajiyama A., Iwatate J., Nishikawa H., Hitomi S., Okuama R., Usui R., Yamada Y., Komaba S. P2-type $\mathrm{Na}(x)[\mathrm{Fe}(1 / 2) \mathrm{Mn}(1 / 2)] \mathrm{O}_{2}$ made from earth-abundant elements for rechargeable Na batteries Nat. Mater. 2012. 11: 512.

7. Delmas C., Fouassier C., Hagenmuller P. Structural classification and properties of the layered oxides. Physica B+C. 1980. 99: 81.

8. Kubota K., Yabuuchi N., Yoshida H., Dahbi M., Komaba S. Layered oxides as positive electrode for Na-ion batteries. MRS Bull. 2014. 39: 416.

9. Mendiboure A., Delmas C., Hagenmuller P. Electrochemical intercalation and deintercalation of $\mathrm{Na}_{x} \mathrm{MnO}_{2}$ bronzes. J. Solid State Chem. 1985. 57: 323.

10. Saadoune I., Maazaz A., M'en'etrier M., Delmas C. On the $\mathrm{Na}_{x} \mathrm{Ni}_{0.6} \mathrm{Co}_{0.4} \mathrm{O}_{2}$ System: Physical and Electrochemical Studies. J. Solid State Chem. 1996. 122: 111.

11. Ellis B.L., Nazar L.F. Sodium and sodium-ion energy storage batteries. Curr. Opin. Solid State Mater. Sci. 2012. 16: 168.

12. Hamani D., Ati M., Tarascon J.-M., Rozier P. $\mathrm{Na}_{x} \mathrm{VO}_{2}$ as possible electrode for Na-ion batteries. Electrochem. Commun. 2011. 13: 938.

13. Bo S., Li X., Toumar A.J., Ceder G. Layered-toRock-Salt Transformation in Desodiated $\mathrm{Na}_{x} \mathrm{CrO}_{2}$ (x 0.4) Chem. Mater. 2016. 28: 1419.

14. Kubota K., Ikeuchi I., Nakayama T., Takei C., Yabuuchi N., Shiiba H., Nakayama M., Komaba S. New Insight into Structural Evolution in Layered $\mathrm{NaCrO}_{2}$ during Electrochemical Sodium
Extraction. J. Phys. Chem C. 2015. 119(1): 166.

15. Xia X., Dahn J.R. $\mathrm{NaCrO}_{2}$ is a Fundamentally Safe Positive Electrode Material for Sodium-Ion Batteries with Liquid Electrolytes. Electrochem. Solid-State Lett. 2011. 15: A1.

16. Fukunaga A., Nohira T., Hagiwara R., Numata K., Itani E., Sakai SK. Nitta. Performance validation of sodium-ion batteries using an ionic liquid electrolyte. Journal of Applied Electrochemistry. 2016. 46(4): 487.

17. Yu Ch., Park J., Jung H., Chung K., Aurbach D., Sun Y., Myung S. $\mathrm{NaCrO}_{2}$ cathode for high-rate sodium-ion batteries. Energy Environ. Sci. 2015. 8: 2019.

18. Tsuchiya Y. and Yabuuchi N. P2- and P3-Type $\mathrm{Na}_{x} \mathrm{Cr}_{x} \mathrm{Ti}_{1-x} \mathrm{O}_{2}$ Layered Oxides As Bi-Functional Electrode Materials for Rechargeable Sodium Batteries. ECS Meeting Abstracts. 2016. MA 2016-02: 768.

19. Parant J.-P., Olazcuaga R., Devalett M., Fouassier C., Hagenmuller P. Sur quelques nouvelles phases de formule $\mathrm{Na}_{x} \mathrm{MnO}_{2}(x \leqslant 1)$. J. Solid State Chem. 1971. 3: 1.

20. Li X., Ma X., Su D., Liu L., Chisnell R., Ong S.P., Chen H., Toumar A., Idrobo J.-C., Lei Y., Bai J., Wang F., Lynn J.W., Lee Y.S., Ceder G. Direct visualization of the Jahn-Teller effect coupled to $\mathrm{Na}$ ordering in $\mathrm{Na}_{5 / 8} \mathrm{MnO}_{2}$. Nat. Mater. 2014. 13: 586.

21. Khan M.A., Han D., Lee G., Kim Y., Kang Y. $\mathrm{P} 2 / \mathrm{O} 3$ phase-integrated $\mathrm{Na}_{0.7} \mathrm{MnO}_{2}$ cathode materials for sodium-ion rechargeable batteries. Journal of Alloys and Compounds. 2019. 771: 987.

22. Billaud J., Singh G., Armstrong A.R., Gonzalo E., Roddatis V., Armand C., Rojo T., Bruce P.G. $\mathrm{Na}_{0.67} \mathrm{Mn}_{1-x} \mathrm{Mg}_{x} \mathrm{O}_{2}(0 \leq \boldsymbol{x} \leq 0.2)$ : a high capacity cathode for sodium-ion batteries. Energy Environ. Sci. 2014. 7: 1387.

23. Yabuuchi N., Hara R., Kubota K., Paulsen J., Kumakura S., Komaba S. A new electrode material for rechargeable sodium batteries: P2-type $\mathrm{Na}_{2 / 3}\left[\mathrm{Mg}_{0.28} \mathrm{Mn}_{0.72}\right] \mathrm{O}_{2}$ with anomalously high reversible capacity. J. Mater. Chem. A. 2014. 40: 16851.

24. Yabuuchi N., Yoshida H., Komaba S. Crystal Struc- 
tures and Electrode Performance of Alpha$\mathrm{NaFeO}_{2}$ for Rechargeable Sodium Batteries. Electrochemistry. 2012. 80: 716.

25. Zhao W., Tsuchiya Y.,Yabuuchi N. Influence of Synthesis Conditions on Electrochemical Properties of P2-Type $\mathrm{Na}_{2 / 3} \mathrm{Fe}_{2 / 3} \mathrm{Mn}_{1 / 3} \mathrm{O}_{2}$ for Rechargeable Na Batteries. Small Methods. 2018. 1800032.

26. Zhao J., Xu J., Lee D.H., Dimov N., Meng Y.S., Okada S. Electrochemical and thermal properties of P2-type $\mathrm{Na}_{2 / 3} \mathrm{Fe}_{1 / 3} \mathrm{Mn}_{2 / 3} \mathrm{O}_{2}$ for Na-ion batteries. J. Power Sources. 2014. 264: 235.

27. Dose W.M., Sharma N., Pramudita J.C., Kimpton J.A., Gonzalo E., Han M.H., Rojo T. Crystallographic Evolution of $\mathrm{P} 2 \mathrm{Na}_{2 / 3} \mathrm{Fe}_{0.4} \mathrm{Mn}_{0.6} \mathrm{O}_{2}$ Electrodes during Electrochemical Cycling_Chem. Mater. 2016. 28: 6342.

28. Mortemard de Boisse B., Carlier D., Guignard M., Bourgeois L., Delmas C. P2- $\mathrm{Na}_{x} \mathrm{Mn}_{1 / 2} \mathrm{Fe}_{1 / 2} \mathrm{O}_{2}$ Phase Used as Positive Electrode in Na Batteries: Structural Changes Induced by the Electrochemical (De)-intercalation Process. Inorg. Chem. 2014. 53: 11197.

29. Shacklette L.W., Jow T.R., Townsend L. Rechargeable Electrodes from Sodium Cobalt Bronzes. J. Electrochem. Soc. 1988. 135: 2669.

30. Berthelot R., Carlier D., Delmas C. Electrochemical investigation of the $\mathrm{P} 2-\mathrm{Na}_{x} \mathrm{CoO}_{2}$ phase diagram. Nat. Mater. 2011. 10: 74.

31. Vassilaras P., Ma X., Li X., Ceder G. Electrochemical Properties of Monoclinic $\mathrm{NaNiO}_{2}$. J. Electrochem. Soc. 2013. 160: A207.

32. Ding J.J., Zhou Y.N., Sun Q., Yu X.Q., Yang X.Q., Fu Z.W. Electrochemical properties of P2- phase $\mathrm{Na}_{0.74} \mathrm{CoO}_{2}$ compounds as cathode material for rechargeable sodium-ion batteries. Electrochim. Acta. 2013. 87: 388.

33. Han M.H., Gonzalo E., Casas-Cabanas M., Rojo T. Structural evolution and electrochemistry of monoclinic $\mathrm{NaNiO}_{2}$ upon the first cycling process. J. Power Sources. 2014. 258: 266.

34. Komaba S., Yabuuchi N., Nakayama T., Ogata A., Ishikawa T., Nakai I. Study on the reversible electrode reaction of $\mathrm{Na}_{1-x \mathrm{Ni} 0.5} \mathrm{Mn}_{0.5} \mathrm{O}_{2}$ for a rechargeable sodium-ion battery. Inorg. Chem. 2012. 51: 6211.

35. Wang H., Yang B., Liao X.-Z., Xu J., Yang D., Yang D., He Y.-S. and Ma Z.-F. Electrochemical properties of $\mathrm{P} 2-\mathrm{Na}_{2 / 3}\left[\mathrm{Ni}_{1 / 3} \mathrm{Mn}_{2 / 3}\right] \mathrm{O}_{2}$ cathode material for sodium ion batteries when cycled in different voltage ranges. Electrochim. Acta. 2013. 113: 200 .

36. Lu Z. and Dahn J.R. In Situ X-Ray Diffraction Study of $\mathrm{P}_{2} \mathrm{Na}_{2 / 3}\left[\mathrm{Ni}_{1 / 3} \mathrm{Mn}_{2 / 3}\right] \mathrm{O}_{2}$. J. Electrochem. Soc. 2001. 148: A1225.

37. Baker J., Heap R. J., Roche N., Tan C., Sayers R., Liu Y. High Performance Na-ion Batteries Based on Novel O3 Layered Oxide Cathode Materials. International Meeting on Lithium Batteries, Como. Italy. 2014.

38. Didier C., Guignard M., Denage C., Szajwaj O., Ito S., Saadoune I., Darriet J., Delmas C. Electrochemical Na-deintercalation from $\mathrm{NaVO}_{2}$. Electrochem. Solid-State Lett. 2011. 14: A75.

39. Komaba S., Takei C., Nakayama T., Ogata A., Yabuuchi N. Electrochemical intercalation activity of layered $\mathrm{NaCrO}_{2}$ vs. $\mathrm{LiCoO}_{2}$. Electrochem. Commun. 2010. 12: 355.

Надійшла 26.06.2019 